\title{
Natural History Observations in the Puerto Rican Dwarf Anole, Anolis occultus Williams and Rivero 1965 (Squamata: Dactyloidae): Nectar-Feeding, Bird Predation, and a Review of the Species' Natural History with Implications for Its Conservation ${ }^{1}$
}

\author{
Neftalí Ríos-López² ${ }^{2}$ José D. Alicea-Ortíz ${ }^{3}$, and \\ Ernesto Burgos-Aponte ${ }^{4}$
}

\begin{abstract}
We document the first record of nectarivory and bird predation in the Puerto Rican Dwarf Anole, Anolis occultus, which expands our knowledge on the natural history in the most diverse genus of Neotropical lizards. In addition, we conducted a literature review on all recorded information about this species, which revealed that little is known about the natural history and the ecology of A. occultus since its description in 1965. A discrepancy exists between the International Union for the Conservation of Nature's (IUCN) and the Puerto Rico's Department of Natural and Environmental Resources' (DNER) listings of A. occultus: 'Least Concern' in the former, 'Data Deficient' in the latter. This discrepancy in international and state listing categories, along with the lack of ecological and historical information on the species, warrants a change of the species' status to 'Data Deficient' by the IUCN, and we recommend areas of ecological research with conservation implications for the species.
\end{abstract}

Key Words: Anole conservation, lagartijo enano, land-use history, twig anole, Anolis occultus, nectarivory, nectivory, bird predation, natural history, conservation

There are 42 species of lizards documented for Puerto Rico by 2016 (including the main island of Puerto Rico and on Mona Island, Desecheo Island, Vieques, Culebra, and satellite islets and cays) of which 13 belong in the genus Anolis (notables: two subspecies, A. cristatellus cristatellus and A. c. wileyae; A. roosevelti, which is presumably extinct). Of those 13 species, ten occur in the mainland of Puerto Rico, with Mona Island, Desecheo Island, and Culebra Island having an endemic anole each. We have garnered field observations about one of the least noticed lizards of Puerto Rico, the Dwarf Anole, A. occultus Williams and Rivero 1965. Herein we include a detailed account on nectarivory by $A$. occultus, the first case reported for this species. Also, we

\footnotetext{
${ }^{1}$ Submitted on April 16, 2016. Accepted on April 21, 2016. Last revisions received on July 25, 2016.

${ }^{2}$ Department of Biology, University of Puerto Rico-Humacao, Call Box 860, Humacao, Puerto Rico 00792 USA. Corresponding author e-mail: neftali.rios@upr.edu, neftalirios@yahoo.com

3 Carretera 172, km 9.4, Barrio Rio Abajo, Cidra, Puerto Rico 00739 USA. E-mail: jdao2010@gmail.com

${ }^{4}$ HC-01 Box 7634, Aguas Buenas, Puerto Rico 00703 USA. E-mail: anolisoccultus12@ gmail.com
} 
document the first case of predation on A. occultus. Given that there is a discrepancy between the International Union for the Conservation of Nature's (IUCN) and the Puerto Rico's Department of Natural and Environmental Resources' (DNER) designations of A. occultus, we undertook a thorough literature review on the species' biology. Based on this review, we recommend that the IUCN changes the status of the A. occultus to 'Data Deficient'.

\section{Nectar-feeding on the Camasey Almendro, Mecranium latifolium ([Cogn.] Skean 1993) (Myrtales: Melastomataceae), by the Dwarf Anole, Anolis occultus}

On October 4, 2016 at 1015h, coauthor JDAO observed an adult male Anolis occultus at a height of $1.8 \mathrm{~m}$ above the ground on a branch of the 'Camasey Almendro'-an evergreen shrub to small tree that can reach $7.6 \mathrm{~m}$ in height and $13 \mathrm{~cm}$ in diameter at breast height-lapping nectar from flowers and from the half-round greenish cuplike base (hypanthium) of unopened flowers in clusters (panicles, Figure 1). The anole deliberately lapped several flowers before crawling up and moving out of sight. This event took place in the vicinity of the road near the main gate that leads to Cerro La Santa $\left(18^{\circ} 06^{\prime} 38.20^{\prime \prime} \mathrm{N}, 66^{\circ} 03^{\prime} 16.40^{\prime \prime} \mathrm{W}\right.$; WGS84), at $829 \mathrm{~m}$ above sea level, adjacent to road PR-184, Barrio Farallón, Cayey municipality, southeastern Puerto Rico.
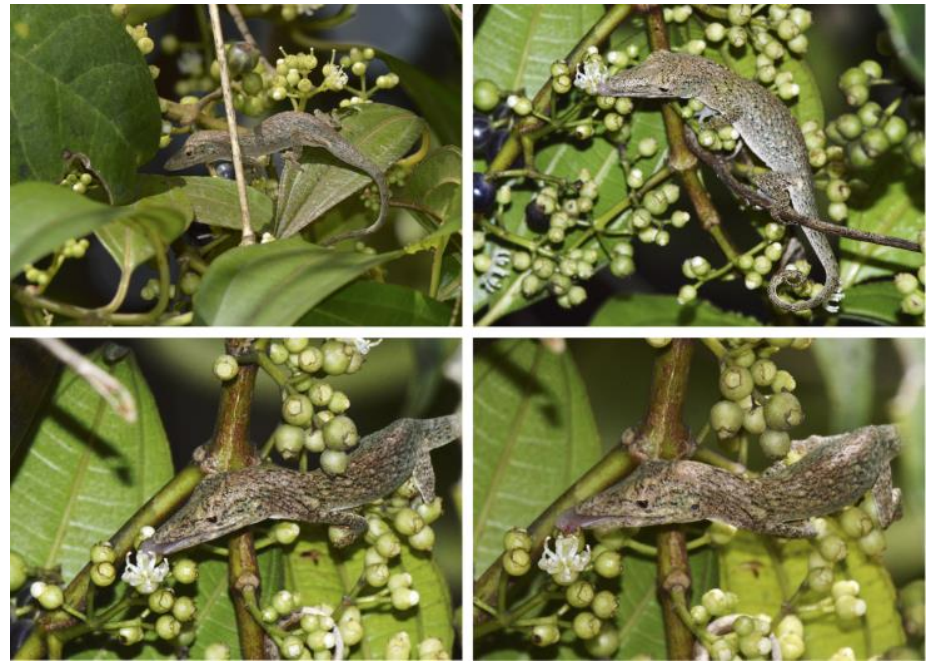

Figure 1. A male Dwarf Anole, Anolis occultus, on an inflorescence of the Camasey Almendro, Mecranium latifolium, showing detail of plant (upper left panel), lapping nectar with its curled tail (upper right panel), and lapping nectar from flower buds (lower panels). This specimen shows typical day-time body coloration (see Thomas 1965 for a thorough description of body coloration in live specimens), with greenish and yellowish tones, and black specs on a gray-light brownish background body coloration. 
To our knowledge, nectar-feeding has been documented in several species of Anolis, including: Green Anole, A. carolinensis Voigt 1832 (Liner 1996, Campbell and Bleazy 2000, Okochi et al. 2006); Graham's Anole, A. grahami Gray 1845 (Losos and de Queiroz 1997); Saddle Anole, A. stratulus Cope 1861 (Perry and Lazell 1997); Grand Cayman Blue-Throated Anole, A. conspersus Garman 1887 (Echternacht and Gerber 2000); Allison's Anole, A. allisoni Barbour 1928 (Valido 2006); Grenadian Bush Anole, A. aeneus Gray 1840 and Grenadian Tree Anole, A. richardii Duméril and Bibron 1837 (Timmermann et al. 2008); Emerald Anole, A. evermanni Stejneger 1904 (Colón-Archilla 2010); Panther Anole, A. bimaculatus Sparrman 1784, Anguilla Bank Anole, A. gingivinus Cope 1864, Anguilla Bank Bush Anole, A. pogus Lazell 1972, and Saban Anole, A. sabanus Garman 1887 (Powell et al. 2005). In addition, extrafloral nectativory has been documented in only two anoles, that are present also in the Puerto Rican Bank: A. stratulus, feeding on nectar from minute round yellow-green glands present between each pair of leaflets (from 3 to 5 leaflets per leave) on the winged axis of the alternate pinnate hairy leaves of the Guaba, Inga vera Willdenow 1806 (Fabales: Fabaceae) (Ríos-López 2004), and A. pulchellus, feeding on nectar from the small elongate gland on the petiole of the bipinnate leaf of the Acacia, Leucaena leucocephala [Lamarck] de Wit 1961 (Fabales: Fabaceae) (Perry and Lazell 2006). This report on nectarivory in A. occultus agrees with Perry and Lazell's (1997) assertion in that nectarivory is far more common among anoles than it is reflected in published accounts.

\section{Bird predation on the Dwarf Anole, Anolis occultus, by the Loggerhead Kingbird, Tyrannus caudifasciatus tylori (P. L. Sclater 1864) (Passeriformes: Tyrannidae)}

On April 27, 2014 at approximately 1500h, coauthor EBA observed an adult Loggerhead Kingbird preying upon an adult Anolis occultus at a height of $4.5 \mathrm{~m}$ above the ground on a branch of a 'Flamboyán' or Flame Tree, Delonix regia (Hook.) Raf. 1837 (Fabales: Leguminosae) (Figure 2). The bird came from an adjacent forest area with the anole in its beak already and flew to this tree, which is planted in the parking lot of the of the 'Hotel Treasure Island' $\left(18^{\circ} 11^{\prime} 04.47^{\prime \prime} \mathrm{N}, 66^{\circ} 08^{\prime} 57.64^{\prime \prime} \mathrm{W}\right.$; WGS84), an area that lies at $421 \mathrm{~m}$ above sea level, Barrio Bayamón, Cidra municipality, central-eastern Puerto Rico. A second Loggerhead Kingbird arrived and perched close to the bird with the anole, which flew out of sight presumably to complete ingestion elsewhere.

Bird predation on West Indian reptiles has been reviewed by Powell and Henderson (2008) and documented the Loggerhead Kingbird preying upon the Caymans Blue-fanned Anole, Anolis conspersus Garman 1887, and the Jamaican Giant Anole, A. oculatus Cope 1879. Ríos-López et al. (2015) reviewed saurophagy (lizard predation) by Puerto Rican vertebrates, including avian predators of Puerto Rican anoles, and found no accounts for the Dwarf Anole. Consequently, the account described herein expands the list of reptile 
preys for the Loggerhead Kingbird in the West Indies (all anoles) and represents the first predation account on A. occultus.

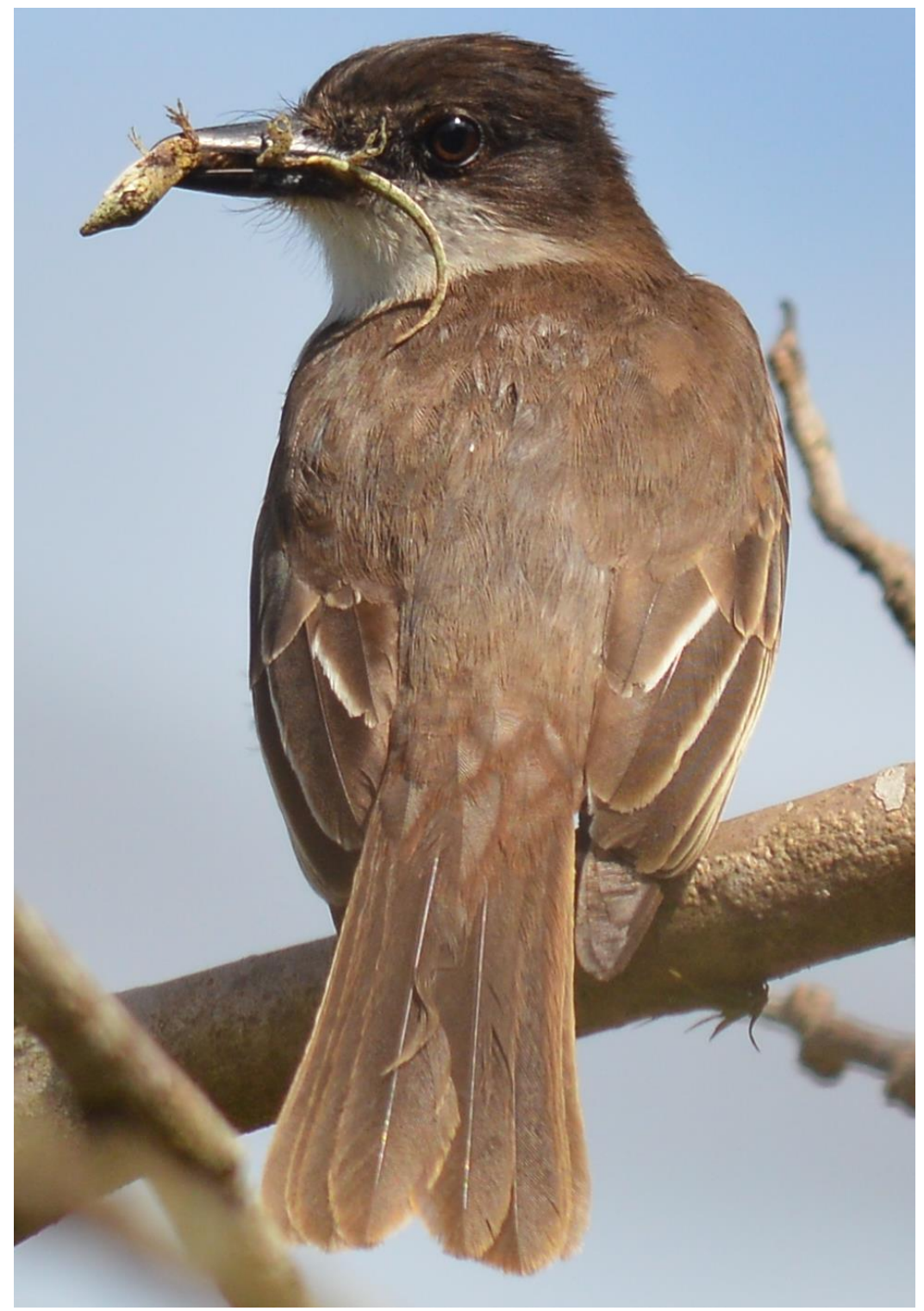

Figure 2. An adult Loggerhead Kingbird, Tyrannus caudifasciatus tylori, with a recently captured adult Dwarf Anole, Anolis occultus. 


\section{Review of recorded information on the natural history and ecology in the Dwaft Anole, Anolis occultus, prior to this study}

The Puerto Rican Dwarf Anole, Anolis occultus Williams and Rivero 1965, is one of the thirteen species described for the region, is the smallest of all Puerto Rican anoles (range of snout-vent length [SVL] $=34-42 \mathrm{~mm}$; Rivero 1998; mean SVL: $38.1 \mathrm{~mm} \pm 0.5 \mathrm{~mm}, N=11$; Losos 1990), and one of the most primitive Puerto Rican anoles (along with the presumably extinct Culebra Island Giant Anole, A. roosevelti Grant 1931, and the Giant Green Anole, A. cuvieri Merrem 1820 (Williams 1972, Rivero 1998, Ojeda-Kessler 2010, Castañeda and de Queiroz 2013). Our literature review revealed that two specimens of $A$. occultus were collected by Williams and Rivero (1965) while Thomas (1965) reported capturing 34 specimens in the original description. All but two of these specimens were collected while animals were sleeping. In his field observations, Thomas (1965) reported that specimens were found on twigs and vines associated with an opening in the canopy (forest gaps), and along narrow path cuts in forest edges (none in closed-canopy areas). Specimens were found at heights from the forest floor (on a leaf axil of the bromeliad Werauhia sintenisii [Baker] J. R. Grant 1995; Williams and Rivero 1965) to $4.5 \mathrm{~m}$ above the ground in tangles of vines and twigs (Thomas 1965). A specimen "may emit a rather persistent squeaking during its struggles to escape" (i.e. release call) when caught or handled (Thomas 1965). Williams and Rivero (1965) and Thomas (1965) provided a detailed description of specimens' external morphology, dewlap shape and color, display and movement (in captivity), chameleon-like eyes and independent movement, and their habit of curling the tail about the vine or twig used as a sleep-site. No reference was made on juveniles, and all specimens collected by Williams, Rivero, and Thomas came from the Cordillera Central: from the Sierra de Cayey in the southeast, to Maricao's upland forests in the central-western mountain range in Puerto Rico. The species' altitudinal distribution ranges from $50 \mathrm{~m}$ to the highest mountain top >1,300 m above sea level (Rivero 1998; Henderson and Powell 2009, de Queiroz and Mayer 2011a).

Webster (1969) added observations of 15 specimens, collected from the Sierra the Luquillo, northeastern Puerto Rico, and confirmed Thomas' observations on sleep posture and release call. In addition, Webster (1969) provided the first observation of a juvenile found on a dead fern during the evening. Gorman (1980) provided observations based on about 25 additional specimens. On several occasions, he observed a male and a female sleeping "within inches from each other" and suggested pair-bonding behavior because the relatively rarity of this species, compared to other species from the island, precluded chance alone (Gorman 1980). Locomotor performance (jumping, clinging, acceleration, and sprint speed) was documented by Losos (1990) based on 11 specimens (jumping and clinging performance), and by Vanhooydonk et al. (2006) based on four specimens (two for acceleration performance and two 
for sprint speed). The species shows no sexual size dimorphism (based on 18 females and seven males, Butler et al. 2000). Molecular and morphological data of A. occultus exist for examining phylogenetic relationships among anoles (e.g., Brandley and de Queiroz 2004, Nicholson et al. 2005, Losos 2009, Kolbe et al. 2011, Nicholson et al. 2012, Castañeda and de Queiroz 2013).

Webster (1969) recorded the first observation of a specimen of Anolis occultus lapping liquid for a short time, when a specimen became active approximately at $0700 \mathrm{~h}$. He described the event: “..., it seemed to drink from raindrops on two occasions and prowled with frequent long pauses over an area of largely bare and exposed twigs, eventually wandering upward and out of sight". Coincidentally, and in support of nectarivory in this species, leaves and flower buds of a shrub of the Melastomataceae (species unknown) is also shown in the foreground in a black and white photograph of a sleeping pair of this species documented in Gorman (1980).

Our literature review revealed that little is known about the natural history of Anolis occultus since its description in 1965; even less is recorded about its ecology (see also Henderson and Powell 2009). Puente-Rolón et al. (unpublished data) characterized nocturnal microhabitat, sleeping posture, sleepsite fidelity, and provided the first estimate of population size for the species in Puerto Rico, specifically in a reforested limestone valley, northern Puerto Rico. Their estimate, 56.1 individuals/ha (A. R. Puente-Rolón, personal communication), represents the lowest population size estimate among all Puerto Rican anoles, only comparable with that from the Giant Anole, A. cuvieri, which is between 39 and 74 individuals/ha in a karst forest (Ríos-López and Puente-Rolón, 2007), and 30 individuals/ha max. in a rain forest (Dial et al., 1994). To contrast, population estimates of other Puerto Rican anoles include (in descending order of population density): between 21,333 and >25,870 individuals/ha in the Saddle Anole, A. stratulus Cope 1861 (Reagan 1992); between 20,000 and 25,000 individuals/ha in the Grass Anole, A. pulchellus Duméril and Bibron 1837 (Gorman and Harwood 1977); between 2,308 individuals/ha in the Emerald Anole, A. evermanni Stejneger 1904, in a rain forest (Dial et al., 1994), and >94 individuals/ha in a karst forest (Ríos-López and Aide 2007); up to 2,000 individuals/ha in the Yellow-Shinned Anole, A. gundlachi Peters 1876 (Turner and Gist 1970); between 1,256 individuals/ha in the Crested Anole, A. cristatellus Duméril and Bibron 1837, in a karst forest (Ríos-López and Aide 2007), and 262 individuals/ha in a dry forest (Genet 2002); between 178 individuals/ha in the Mountain Garden Anole, A. krugi Peters 1876, in a lowland reforested karst valley (Ríos-López and Aide 2007), and 100 individuals/ha in an upland coffee plantations (Borkhataria et al. 2012); and up to $\sim 198$ individuals/ha in the Dry Forest Anole, A. cooki Grant 1931 (Genet 2002). As far as we know, there are no estimates of population size for: the Desecheo Island Anole, A. desechensis Heatwole 1976; Mona Island Anole, 
A. monensis Stejneger 1904; Dryland Grass Anole, A. poncensis Stejneger 1904; and the Culebra Island Giant Anole, A. roosevelti Grant 1931.

Anolis roosevelti, which is presumably extinct (Ojeda-Kessler 2010), is listed as Critically Endangered by the Puerto Rico's Department of Natural and Environmental Resources (DNER 2015) and as Endangered by the U.S. Fish and Wildlife Service (the only Puerto Rican anole listed by the federal agency). In addition, the DNER (2015) lists $A$. cooki as Endangered, A. poncensis as Vulnerable, and A. cuvieri and A. occultus as Data Deficient. Only two Puerto Rican anoles, however, have been assessed by the International Union for the Conservation of Nature (IUCN) in its Red List of Threatened Species: A. roosevelti, listed as Critically Endangered (de Queiroz and Mayer 2011b), and A. occultus, which is listed as Least Concern (de Queiroz and Meyer 2011a). As for A. occultus, however, there is no estimate of population size and density for the species elsewhere on the island except that estimated by Puente-Rolón (unpublished data and personal communication), nor data on home range, demography and reproductive phenology, longevity, physiology, mating behavior, feeding ecology, parasites and pathogens, intra- and inter-specific interactions, nor molecular data on the species' genetic structure and gene flow within and among populations. While some of these data are lacking for most anoline species from Puerto Rico, the whole suit of data is lacking for $A$. occultus, except that now we know it has the lowest estimated population size among all Puerto Rican anoles for which this data exist.

\section{Research needs, Puerto Rico's land-use history, and climate change: Implications for conservation status of Anolis occultus}

Williams' (1972) considered Anolis occultus among the ten species that are "ecologically well studied on the mainland of Puerto Rico." In contrast, Gorman (1980, p. 30) mentioned that "I suggest that compared to most of the other species of Puerto Rican anoles, A. occultus is relatively rare; although in the complete absence of demographic studies I hesitate to define this expression." From that moment on, several authors have listed the species' population status, either as 'Stable' (Moreno 1991) or 'Least Concern' (de Queiroz and Mayer 2011a). Specifically, de Queiroz and Mayer (2011a) in the International Union for the Conservation of Nature (IUCN) mention that "Anolis occultus has been assessed as Least Concern due to its relatively wide range across Puerto Rico, protection from managed forests and the national park, and a lack of current threats. Furthermore, it is unlikely that any population declines are being experienced by A. occultus. Monitoring of this species population and distribution should be carried out to ensure declines are highlighted and the appropriate conservation measures put in place". However, neither Moreno (1991) nor de Queiroz and Mayer (2011a) provided data to support the recommended listing categories, 'Stable' and 'Least Concern', respectively. Authors de Queiroz and Mayer (2011a) do mentioned that "In the past there had 
been much deforestation across Puerto Rico, but in recent decades reforestation has occurred and therefore land destruction and degradation are no longer a major threat to this species." We believe that Puerto Rico's land-use history is worth noting next from the context of the species' 'Least Concern' listing.

Hill (1899), a prominent and pioneer Texan geologist at the time, vividly described the forest conditions of Puerto Rico by the time of arrival of the United States to Puerto Rico in 1898. Several passages from Hill (1899, pp. 1617) are highlighted here: "Owing to this soil the mountains were originally wooded and are now cultivated to their very summits, verticality of slope presenting no obstacle to cultivation in the minds of the natives. The writer has seen the steepest possible slopes cultivated to the highest degree in coffee and tobacco; in fact, the most productive crops of this character are grown upon declivities upon which the American farmer would not risk limb and life." Hill (1899, pp. 17-18) continues: "Much of the soil of Porto Rico is now abandoned and in the condition known throughout the English-speaking West Indies as "ruinate." This has resulted from long cultivation, from the failure to apply fertilizers, and, in some cases, from erosion."..."In the western part of the island, in the high summit region, seen in passing from Adjuntas to Lares, many abandoned fields were observed, which are now entirely denuded of trees and cultivated crops." Domínguez-Cristóbal (2000) reported that this wide-scale deforested status of Puerto Rican forests (mainly for agriculture and timber extraction) was already evident by the early 1800s. Lugo (2004) reported that by the 1940s, approximately $6 \%$ of forest cover remained because of the Puerto Rican economy was still based on agriculture, with just about $1 \%$ of the original forest area remaining unmodified at the time. After the 1940s, the Puerto Rican economy then shifted, from agriculture to industry (Dietz 1987), resulting in a $42 \%$ forest recovery by natural means $\sim 60$ years afterwards because of abandonment of deforestation for large-scale agriculture and a corresponding rural-urban migration (Grau et al. 2003, Grau and Aide 2007, Parés-Ramos et al. 2008).

Regeneration of Puerto Rican forests, however, was possible because of introduced plant species, which created new forests of different species composition compared to native forests (those without introduced species) (Martinuzzi et al. 2013). In addition, these secondary forests reached environmental and microclimatic conditions similar to native forests in about 40 years after abandonment (Grau et al. 2003, Martinuzzi et al. 2013), with species richness and physical structure similar to native forest stands of similar age, but between 60 and 80 years after abandonment (Lugo and Helmer 2004). On the other hand, evidence suggest that Anolis occultus is a rare forest-interior species (Borkhataria et al. 2012) that seems to prefer native-forest gaps and edges (Thomas 1965, de Queiroz and Mayer 2011a). Therefore, we believe that despite this "rapid" forest recovery time, novel forests of different plant composition that resulted from this recovery may have isolated populations of $A$. 
occultus mostly in native forest patches for a considerable time span-yet unknown-in relation to the the species' presumably short generation time. Currently, estimates of native forests coverage in Puerto Rico (reviewed by Martinuzzi et al. 2013) that could be suitable for finding A. occultus is $4.2 \%$ of Puerto Rico's land area (thus representing the smallest geographic distribution among anoles on the mainland of Puerto Rico). The IUCN reports A. occultus as having a wide geographic distribution (de Queiroz and Mayer 2011a), but land-use history revealed that this is not equivalent to a continuous geographic distribution nor a corresponding species' high abundance. Consequently, with no population size data on the species along its geographic distribution, we may tentatively suggest that populations of the species may have remained fragmented mostly in those patches of isolated native mountain forests, at least from the species' discovery time to most of present time. In fact, we believe $A$. occultus may have a presumably limited recolonization capacity to these novel forests that characterized post-agriculture Puerto Rico. To illustrate, Borkhataria (2001) mentioned on anoles that "Although all species were seen on coffee plants during the course of this study, A. occultus was extremely rare and recorded only once during all sampling occasions." We believe that population expansion by $A$. occultus to adjacent regenerated forests, particularly in the northern karst region, may have occurred, but at some considerable time after land abandonment: as variation in ambient temperature decreased and relative humidity increased with increasing vegetation cover during secondary succession (see Ríos-López and Aide 2007 for a discussion on animal assembly rules during secondary succession). Nonetheless, the lack of ecological and physiological data on the species (particularly that relevant for estimating home range) precluded us to state a definitive colonization time and population expansion after land abandonment.

We emphasize the need to generate detailed ecological studies throughout the species' geographic distribution as these studies are of paramount importance for conservation considerations. Firstly, as we are living in a human-dominated world (sensus Vitousek et al. 1997), knowledge of land-use history is particularly important for conservation purposes in Puerto Rico and elsewhere. Secondly, reptiles are declining (Gibbons et al. 2000) and habitat loss is considered the leading cause of their declines globally (Todd et al. 2010). As for Anolis occultus-and many other mountain forest dwellers as well-a third fact threatening the species might be even more important today: climate change. To illustrate, Puerto Rico's 2010 census revealed that $61 \%$ of human population in Puerto Rican jurisdiction occurs in coastal municipalities (U.S. Census Bureau 2012). In addition, former agriculture lands and secondary forests in costal areas are being transformed to urban and industry (Parés-Ramos et al. 2008). The Puerto Rico Climate Change Council (2013) agreed that coastal areas in Puerto Rico are already under imminent threat in the near future because of sea-level rise due to global warming. The question remained on 
when and how much, but recently, Hansen et al. (2016) asserted that global warming has reached a global emergency mark, with sea-level rise reaching several meters in at least 50 years from now. Consequently, we might expect that the natural regeneration of secondary forests in mountain areas that characterized Puerto Rico during the past $70-80$ years will be severely threatened, if not reverted, by a corresponding urban-rural migration due in large part to socio-economic dynamics (which is occurring already, Parés-Ramos et al. 2008, Borkhataria et al. 2012), along with ecological responses to sea-level rise, salt-water intrusion, coastal erosion, and a corresponding upland migration of mixed-vegetation forests as well (for examples on costal forests and amphibians see Rivera-Ocasio et al. 2007 and Ríos-López 2008, respectively). In addition, current Puerto Rican economy so far experiences a $\sim 10$ years economic depression and the government sponsors wide-scale agriculture projects, particularly in state-owned abandoned agriculture uplands, as part of the island's economic recovery plan. Considering that much of our former agriculture land-cover was lost to urbanization and it is still being urbanized (Puerto Rico Environmental Quality Board 2014), we believe that regenerated forests, and most importantly, natural mountain forests suitable for a forestinterior species like A. occultus (and other forest-interior anoles), will be under tremendous pressure by human activities and climate in the imminent future.

We agree with de Queiroz and Mayer (2011a) in that Anolis occultus' population status is still unknown and that "further research into the threats, population, and habitat trends are needed to ensure this species is not in decline." In fact, we believe that such studies are strongly needed not only for A. occultus, but for the vast majority of reptiles (and amphibians) from Puerto Rico (and elsewhere). This may explain why the DNER reassessed Moreno's (1991) species' 'Stable' status, and lists A. occultus as 'Data Deficient' instead (DNER 2015). Moreover, the only references to the species' abundance highlight the rarity of the species (e.g., Gorman 1980, Borkhataria 2001, Borkhataria et al. 2012, A. R. Puente-Rolón et al. unpublished data and personal communication), and the acknowledgement of the lack of information on the species' abundance from a wide range on environmental conditions and of other biological aspects reviewed herein, calls for a reassessment of the IUCN's species population status, from 'Least Concern' to 'Data Deficient'. We recommend that 'Data Deficient' is a more accurate status for A. occultus because it may lead also to these much-needed ecological studies on the species for its effective conservation, considering the Puerto Rico's land-use history, socio-economic dynamics, and information on climate change projections and Puerto Rico's habitat modifications expected in the imminent future.

\section{Acknowledgments}

We wish to thank four anonymous reviewers for valuable comments that greatly improved this manuscript. 


\section{Literature Cited}

Angulo, A. 2008a. Eleutherodactylus portoricensis. The IUCN Red List of Threatened Species 2008: e.T56875A11547757. http://dx.doi.org/10.2305/IUCN.UK.2008.RLTS.T56875A11547757.en. Downloaded on 15 April 2016.

Angulo, A. 2008b. Eleutherodactylus wightmanae. The IUCN Red List of Threatened Species: e.T57056A11575451. http://dx.doi.org/10.2305/IUCN.UK.2008.RLTS.T57056A11575451.en. Downloaded on 15 April 2016.

Borkhataria, R. R. 2001. Ecological and political implications of conversion from shade to sun coffee in Puerto Rico. M.S. Thesis. North Carolina State University, Department of Zoology. $149 \mathrm{pp}$.

Borkhataria, R., J. A. Collazo, M. J. Groom, A. Jordan-Garcia. 2012. Shade-grown coffee in Puerto Rico: opportunities to preserve biodiversity while reinvigorating a struggling agricultural commodity. Agriculture, Ecosystems and Environment 149:164-170. http://dx.doi.org/10.1016/j.agee.2010.12.023

Brandley, M. C. and K. de Queiroz. 2004. Phylogeny, ecomorphological evolution, and historical biogeography of the Anolis cristatellus series. Herpetological Monographs 18:90-126. http://dx.doi.org/10.1655/0733-1347(2004)018[0090:PEEAHB]2.0.CO;2

Butler, M. A., T. W. Shoener, and J. B. Losos. 2000. The relationship between sexual size dimorphism and habitat use in Greater Antillean Anolis lizards. Evolution 54(1):259-272. http://dx.doi.org/10.1554/0014-3820(2000)054[0259:trbssd]2.0.co;2

Campbell, T. and C. Bleazy. 2000. Natural history notes: Anolis carolinensis (green anole). Nectivory and flower pollination. Herpetological Review 31:239.

Castañeda, M. Del R. and K. de Queiroz. 2013. Phylogeny of the Dactyloa Clade of Anolis lizards: new insights from combining morphological and molecular data. Bulletin of the Museum of Comparative Zoology 160(7):345-398. http://dx.doi.org/10.3099/0027-4100-160.7.345

Colón Archilla, A. D. 2010. Nectivory in Puerto Rican emerald anoles (Anolis evermanni). International Reptile Conservation Foundation (IRCF) Reptiles and Amphibians 17:144-145.

de Queiroz, K. and Mayer, G.C. 2011a. Anolis occultus. The IUCN Red List of Threatened Species 2011: $\quad$ e.T178657A7589838. $\quad$ http://dx.doi.org/10.2305/IUCN.UK.20111.RLTS.T178657A7589838.en. Downloaded on 01 July 2016.

de Queiroz, K. and G. C. Mayer. 2011b. Anolis roosevelti. The IUCN Red List of Threatened Species 2011: $\quad$ e.T1319A3418702. http://dx.doi.org/10.2305/IUCN.UK.20111.RLTS.T1319A3418702.en. Downloaded on 01 July 2016.

Dial, R., J. Roughgarden, and S. C. Tobin. 1994. Notes on the absolute abundance of canopy anoles, Anolis cuvieri, A. stratulus, and A. evermanni (Lacertilia: Polychrotidae) in the Luquillo Forest, Puerto Rico. Caribbean Journal of Science 30:278-279.

Dietz, J. L. 1989. Historia Económica de Puerto Rico. Ediciones Huracán. Río Piedras, San Juan, Puerto Rico. 358 pp.

Department of Natural and Environmental Resources (DNER). 2015. Puerto Rico State Wildlife Action Plan: Ten Year Review. Puerto Rico Department of Natural and Environmental Resources (September 2015). San Juan, Puerto Rico. 187 pp.

Domínguez-Cristóbal, C. M. 2000. Panorama Histórico Forestal de Puerto Rico. Editorial de la Universidad de Puerto Rico. San Juan, Puerto Rico. pp. 704.

Echternacht, A. C. and G. P. Gerber. 2000. Anolis conspersus (Grand Cayman Blue throated Anole). Nectivory. Herpetological Review 31:173.

Genet, K. S. 2002. Structural habitat and ecological overlap of the Puerto Rican lizards Anolis cristatellus and $A$. cooki, with comments on the long-term survival and conservation of $A$. cooki. Caribbean Journal of Science 38(3-4):272-278.

Gibbons, J. W., D. E. Scott, T. J. Ryan, K. A. Buhlmann, T. D. Tuberville, B. S. Metts, J. L. Greene, T. Mills, Y. Leiden, S. Poppy, and C. T. Winne. 200. The global declines of reptiles, déjà vu amphibians. BioScience 50(8):653-666.

Gorman, G. C. 1980. Anolis occultus, a small cryptic canopy lizard: are there pair bonds? Caribbean Journal of Science 15(3-4):29-31. 
Grau, H. R. and T. M. Aide. 2007. Are rural-urban migration and sustainable development compatible in mountain sustems? Mountain Research and Development 27(2):119-123. http://dx.doi.org/10.1659/mrd.0906

Grau, H. R., T. M. Aide, J. K. Zimmerman, J. R. Thomlinson, E. Helmer, and X. Zou. 2003. The ecological consequences of socioeconomic and land-use changes in postagriculture Puerto Rico. BioScience 53(12):1159-1168. http://dx.doi.org/10.1641/00063568(2003)053[1159:TECOSA]2.0.CO;2

Gorman, G. C. and R. Harwood. 1977. Notes on population density, vagility, and activity patterns of the Puerto Rican grass lizard, Anolis pulchellus (Reptilia, Lacertilia, Iguanidae). Journal of Herpetology 11:363-368. http://dx.doi.org/10.2307/1563250

Hansen, J., M. Sato, P. Hearty, R. Ruedy, M. Kelley, V. Masson-Delmotte, G. Russell, G. Tselioudis, J. Cao, E. Rignot, I. Velicogna, B. Tormey, B. Donovan, E. Kandiano, K. von Schuckmann, P. Kharecha, A. N. Legrande, M. Bauer, and K.W. Lo. 2016. Ice melt, sea level rise and superstorms: evidence from paleoclimate data, climate modeling, and modern observations that $2^{\circ} \mathrm{C}$ global warming could be dangerous. Atmospheric Chemistry and Physics 16:3761-3812. http://dx.doi.org/10.5194/acp-16-3761-2016

Henderson, R. W. and R. Powell. 2009. Natural History of West Indian Reptiles and Amphibians. University Press of Florida. Gainesville, Florida, USA. 528 pp.

Hill, R. T. 1899. Notes on the Forest Conditions of Porto Rico. Bulletin No. 25. Division of Forestry, United States Department of Agriculture. Washington, District of Columbia, USA. 48 pp. http://www.biodiversitylibrary.org/search?searchTerm=Notes+on+the+Forest+Conditions+of + Porto+Rico\#/titles

Kolbe, J. J., L. J. Revell, B. Szekely, E. D. Brodie III, and J. B. Losos. 2011. Convergent evolution of phenotypic integration and its alignment with morphological diversification in Caribbean Anolis ecomorphs. Evolution 65-12:3608-3624. http://dx.doi.org/10.1111/j.15585646.2011.01416.x

Liner, E. A. 1996. Natural history notes: Anolis carolinensis carolinensis (green anole). Nectar feeding. Herpetological Review 27:78.

Losos, J. B. 1990. Ecomorphology, performance capability, and scaling of West Indian Anolis lizards: an evolutionary analysis. Ecological Monographs 60(3):369-388. http://dx.doi.org/10.2307/1943062

Losos, J. B. 2009. Lizards in an Evolutionary Tree: Ecology and Adaptive Radiation of Anoles. University of California Press. Berkeley, California, USA. 507 pp.

Losos, J. B. and K. de Queiroz. 1997. Darwin's lizards. Natural History 106:34-39.

Lugo, A. E. 2004. The outcome of alien tree invasions in Puerto Rico. Frontiers in Ecology and the Environment 2(5):265-273. http://dx.doi.org/10.1890/1540-9295(2004)002[0265:TOOATI]2.0.CO;2

Lugo, A. E. and E. Helmer. 2004. Emerging forests on abandoned land: Puerto Rico's new forests. Forest Ecology and Management 190:145-161. http://dx.doi.org/10.1016/j.foreco.2003.09.012

Martinuzzi, S., A. E. Lugo, T. J. Brandeis, and E. H. Helmer. 2013. Case study: geographic distribution and level of novelty of Puerto Rican forests. pp. 81-87. In, Hobbs, R. J., E. S. Higgs, and C. M. Hall (Editors). Novel Ecosystems: Intervening in the Ecological World Order, First Edition. John Wiley and Sons, Ltd. Chichester, West Sussex, England, UK. Hoboken, New Jersey, USA. http://site.ebrary.com/lib/alltitles/docDetail.action?docID=10657803

Moreno, J. A. 1991. Appendix II. Status recommendations/recomendaciones de designation. pp. 6567. In, Moreno, J. A. (Editor). Status y Distribución de los Reptiles y Anfibios de la Región de Puerto Rico. Publicación Científica Miscelánea No. 1. Departamento de Recursos Naturales de Puerto Rico, San Juan, Puerto Rico. 67 pp.

Nicholson, K. E., B. I. Crother, C. Guyer, and J. M. Savage. 2012. It is time for a new classification of anoles (Squamate: Dactyloidae). Zootaxa 3477:1-108. http://dx.doi.org/10.1111/j.13652699.2004.01222.x

Nicholson, K. E., R. E. Glor, J. J. Kolbe, A. Larson, S. B. Hedges, and J. B. Losos. 2005. Mainland colonization by island lizards. Journal of Biogeography 32:929-938. http://dx.doi.org/10.1111/j.1365-2699.2004.01222.x 
Ojeda-Kessler, A. G. 2010. Status of the Culebra Island Giant Anole (Anolis roosevelti). Herpetological Conservation and Biology 5(2):223-232.

Okochi, I., M. Yoshimura, T. Abe, and H. Suzuki. 2006. High population densities of an exotic lizard, Anolis carolinensis and its possible role as a pollinator in the Ogasawara Islands. Bulletin of the Forestry and Forest Products Research Institute 5:265-269.

Parés-Ramos, I. K., W. A. Gould, and T. Mitchell Aide. 2008. Agricultural abandonment, suburban growth, and forest expansion in Puerto Rico between 1991 and 2000. Ecology and Society 13(2): 1. [online] URL: http://www.ecologyandsociety.org/vol13/iss2/art1/

Perry, G. and J. Lazell. 1997. Anolis stratulus (Saddled Anole). Nectivory. Herpetological Review 28:150-151.

Perry, G. and J. Lazell. 2006. Anolis pulchellus (Grass Anole). Nectivory. Herpetological Review 37:218-219.

Powell, R. and R. W. Henderson. 2008. Avian predators of West Indian Reptiles. Iguana 15(1):9-11.

Powell, R., R. W. Henderson, and J. S. Parmerlee, Jr. 2005. The Reptiles and Amphibians of the Dutch Caribbean: St. Eustatius, Saba, and St. Marteen. The St. Eustatius National Parks Foundation (STENAPA), Gallows Bay, St. Eustatius, Netherlands Antilles. 192 pp.

Puerto Rico Climate Change Council (PRCCC). 2013. Puerto Rico's State of the Climate 20102013: Assessing Puerto Rico's Social-Ecological Vulnerabilities in a Changing Climate. Puerto Rico Coastal Zone Management Program, Department of Natural and Environmental Resources, NOAA Office of Ocean and Coastal Resource Management. San Juan, PR. 316 pp. http://pr-ccc.org/download/PR\%20State\%20of\%20the\%20Climate-FINAL_ENE2015.pdf

Puerto Rico Environmental Quality Board. 2014. Environmental Report. Governing Board, and Area Evaluation and Strategic Planning, Environmental Quality Board. San Juan, PR. 149 pp. http://www2.pr.gov/agencias/jca/Documents/Publicaciones\%20de\%20Inter\%C3\%A9s/Informe s\%20Ambientales/Informe\%20Ambiental\%202014/Informe\%20Ambiental\%202014.pdf

Reagan, D. P. 1992. Congeneric species distribution and abundance in a three-dimensional habitat: the rain forest anoles of Puerto Rico. Copeia 1992(2):392-403. http://dx.doi.org/10.2307/1446199

Ríos-López, N. 2004. Anolis stratulus (Saddled Anole). Extrafloral nectivory. Herpetological Review 35:386.

Ríos-López, N. 2008. Effects of increased salinity on tadpoles of two anurans from a Caribbean coastal wetland in relation to their natural abundance. Amphibia-Reptilia 29:7-18. http://dx.doi.org/10.1163/156853808783431451

Ríos-López, N. and T. M. Aide. 2007. Herpetofaunal dynamics during secondary succession. Herpetologica 63(1):35-50. http://dx.doi.org/10.1655/0018-0831(2007)63[35:HDDSS]2.0.CO;2

Ríos-López, N. and A. R. Puente-Rolón. 2007. Anolis cuvieri (Puerto Rican Giant Anole). Reproductive Ecology. Herpetological Review 38(1):73-75.

Ríos-López, N., R. L. Joglar, C. A. Rodríguez-Gómez, C. J. Díaz-Vázquez, and I. Rivera. 2015. Natural history notes of saurophagy: an update from the Puerto Rican vertebrate fauna. Life: The Excitement of Biology 3(2):118-136. http://dx.doi.org/10.9784/LEB3(2)Rios.02

Rivera-Ocasio, E., T. M. Aide, and N. Ríos-López. 2007. The effects of salinity on the dynamics of a Pterocarpus officinalis forest stand in Puerto Rico. Journal of Tropical Ecology 23:559-568. http://dx.doi.org/10.1017/S0266467407004361

Rivero, J. A. 1998. The Amphibians and Reptiles of Puerto Rico. Second Edition. Editorial de la Universidad de Puerto Rico, San Juan, Puerto Rico, USA. 510 pp.

Thomas, R. 1965. A new anole (Sauria: Iguanidae) from Puerto Rico. Part II. Field Observations on Anolis occultus Williams and Rivero. Breviora 231:10-18.

Timmermann, A., B. Dalsgaard, J. M. Olesen, L. H. Andersen, and A. M. Martín González. 2008. Anolis aeneus (Grenadian Bush Anole). Anolis richardii (Grenadian Tree Anole). Nectivory/pollination. Herpetological Review 39:84-85.

Todd, B. D., J. D. Willson, and J. W. Gibbons. 2010. The global status of reptiles and causes of their decline. pp. 47-67. In, Linder, D. W., G. Bishop, and S. Krest (Editors). Ecotoxicology of Amphibians and Reptiles, Second Edition. CRC Press. New York, NY, USA. pp. 944.

Turner, F. B. and C. S. Gist. 1970. Observation of lizards and frogs in an irradiated Puerto Rican forest. Chapter E-2. pp. E25-E49. In, Odum, H. T. and R. F. Pigeon (Editors). A Tropical Rain 
Forest: a study of irradiation and ecology at El Verde, Puerto Rico. United States Atomic Energy Commission. Oak Ridge, Tennessee, USA. 1674 pp.

United States Census Bureau. 2012. 2010 Census of Population and Housing: Summary Population and Housing Characteristics, CPH-1-53, Puerto Rico. United States Government Printing Office. Washington, District of Columbia, USA. 475 pp.

Valido, A. M. 2006. Anolis allisoni (Allison's Anole/Cameleon Azul). Nectar feeding. Herpetological Review 37:461.

Vanhooydonck, B., A. Herrel, R. Van Damme, and D. J. Irschick. 2006. The quick and the fast: the evolution of acceleration capacity in Anolis lizards. Evolution 60(10):2137-2147. http://dx.doi.org/10.1111/j.0014-3820.2006.tb01851.x

Vitousek, P. M., H. A. Mooney, J. Lubchenco, and J. M. Malillo. 1997. Human domination of Earth's ecosystems. Science (277):494-499. http://dx.doi.org/10.1126/science.277.5325.494

Webster, T. P. 1969. Ecological observations on Anolis occultus Williams and Rivero (Sauria, Iguanidae). Breviora 312:1-5.

Williams, E. E. 1972. The origin of faunas. Evolution of lizard congeners in a complex island fauna: a trial analysis. pp. 47-89. In, Dobzhansky, T. H., M. K. Hecht, and W. M. C. Steere (Editors). Evolutionary Biology Volume 6. Appleton - Century - Crofts. Educational Division / Meredith Corporation. New York, NY, USA. 445 pp. doi: 10.1007/978-1-4684-9063-3_3

Williams, E. E. and J. A. Rivero. 1965. A new anole (Sauria: Iguanidae) from Puerto Rico. Part I. Description. Breviora 231:1-9. 